\title{
Analysis of the Effect of Quality, Service Price and Satisfaction on Patients and Their Impact on Visits to Exclusive Dental Clinics in South Jakarta
}

\author{
Aji Gempur Pamungkas ${ }^{1}$, Arief Suharko ${ }^{2}$, Desy Apriani ${ }^{3}$, Jawahir ${ }^{4}$, Efa Ayu Nabila ${ }^{5}$ \\ ${ }^{1,2}$ Universitas Bakrie, Kawasan Rasuna Epicentrum, Jl. H. R. Rasuna Said No.2, RT.2/RW.5, Karet, \\ Kecamatan Setiabudi, Kuningan, Daerah Khusus Ibukota Jakarta 12940, Indonesia \\ ${ }^{3,4,5}$ University of Raharja, Modern, Jl. Jenderal Sudirman No.40, Cikokol, Kec. Tangerang, Kota Tangerang, \\ Banten 15117, Indonesia ${ }^{5}$ Information Technology, University of Raharja, Tangerang, Indonesia \\ 19admisi@bakrie.ac.id, ${ }^{2}$ arief.suharko@bakrie.ac.id, ${ }^{3}$ desy@ raharja.info, ${ }^{4}$ jawahir@ raharja.ac.id ${ }^{5}$ efaayunabila@ raharja.info
}

\begin{abstract}
Article Info
Article history:

Received 12-14-2021

Revised 12-29-2021

Accepted 01-01-2022

\section{Keywords:}

Exclusive dental clinic service quality service price patient satisfaction patient loyalty

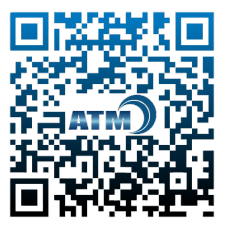

ABSTRACT

The low rate of repeat visits in exclusive dental clinics is an interesting problem to study. From the available data, as well as interviews with several owners of exclusive dental clinics in cities of Jakarta, Surabaya, Samarinda and Banjarmasin in Indonesia as well as from the initial observations at exclusive dental clinics in South Jakarta, we found that the rate of repeat visits for existing patients was much lower than for new patients. From previous studies, it was also found that patient visits to the dental clinic were very low. This was influenced by the low level of patient satisfaction with the dental clinic.Their article mentions that retaining existing patients who make repeat visits at health clinics is about five times more profitable than serving new patients. This study aims to determine the effect of quality, service price and patient satisfaction on patient loyalty which influences patients to make repeat visits to exclusive dental clinics in South Jakarta, Indonesia. The subjects of this study were patients who had made at least two visits to the same exclusive dental clinics in South Jakarta, as well as patients who had previously visited other exclusive dental clinics. In this study, the approach used is a quantitative approach, and the type of data used in this study uses quantitative data in the form of questionnaire tabulations and qualitative data in the form of the research object general observations. We collect primary data through respondents' answers to questionnaires and secondary data sources through information on the population of DKI Jakarta Selatan and the characteristics of the middle-upper economic community.
\end{abstract}

This is an open access article under the CC BY-SA license.

\section{Corresponding Author:}

Efa Ayu Nabila

University of Raharja, Tangerang, Indonesia

Email: efaayunabila@raharja.info

\section{INTRODUCTION}

The development of science and technology today directly influences competition in the business world; both businesses engaged in goods and companies engaged in services. Good quality goods and services are the primary keys in winning the competition; good quality products will provide a good satisfaction value to customers.[1]Science and technology also contribute to the development of society, where people are more educated and knowledgeable. With the more academic and broad knowledge of the community, this will result 
in their increasing socio-economic status being better than before. Quoting from the Ministry of Finance of the Republic of Indonesia (2019) website[2], Minister of Finance Sri Mulyani said more than 50 million Indonesians belong to the upper-middle class. the Minister of Finance, the middle-upper class will impact the Indonesian economy, especially in terms of demand and lifestyle. [3]The upper-middle-class likes an experienced lifestyle, such as looking for healthy food, healthy drinks and starting to think of health as a lifestyle and investment. With a lifestyle like that, it will form an extraordinary market. If there is demand, supply will respond. Currently, the middle-upper class economy's demand changes business actors' business opportunities from niche to wants. So it is not just the clothes you wear, but it must be beautiful.[4]

In the field of dentistry, the number of public visits to dental clinics is still deficient; according to research conducted by Taqiyyah, La Ode, Paridah, it is stated that several aspects of health services can affect the perception of someone who uses health services, including aspects of patient satisfaction, exceptionally patient satisfaction. To curative services. Usually, when health services are good, patients will continue to choose these service facilities for treatment; aspects of service quality are also in the spotlight, such as the ability of health workers to provide services, the availability of facilities, or the attitude of officers in serving patient complaints and needs. The poor quality of health services is the cause of the low level of community visits to dental clinic services. Of course, the level of visits to dental health services can be increased if the quality of dental health servicesmeets people's expectations.[5]

Seeing the vast market potential of the upper-middle segment where experience and quality are essential for the upper-middle segment market coupled with a healthy lifestyle that has become a trend among the middle-upper segment market will undoubtedly be a potential business opportunity for dentists. [6] Dewanto stated that along with its development, the middle-upper segment market increasingly demands quality and good dental health services. This can be achieved by providing quality health services in a climate of fair competition. The need for quality health services with additional convenience services is increasing along with the much middle-upper class in the country. This can also be seen in the increasing number of exclusive dental clinics in Jakarta, especially South Jakarta, which offer a one-stop service.[7] Heesup Sunghyup, in their research conducted in South Korea, it was stated that loyalty in the form of repeat visits is the primary key to the success of health clinics. Repeat visits are influenced by service quality and service prices, so they impact patient satisfaction. There will be loyalty from patients who use health services and services from patient satisfaction. Realizing the importance of these factors, each health clinic is becoming more and more concerned about managing and improving service quality and providing prices that are acceptable to patients so that patients will feel satisfied, so it is hoped that patient loyalty will arise.

The author has conducted initial interviews with several owners of exclusive dental clinics in several big cities in Indonesia, such as Jakarta, Surabaya, Banjarmasin, and Samarinda. From the initial interview, an interesting problem wasfound, where the owners of the dental clinic stated that the number of patients who were loyal to their dental clinic was minimal, this could be seen from the minimal number of patient repeat visits to their clinic. Most of their patients are new patients, who come only when they have a toothache.Mahrous Hifnawy, in their journal, mentions that dentists are different from general practitioners who prioritize the number of sick patient visits, both new patients and old patients who make repeat visits so that their practice business achieves economic benefits as desired by the general practitioner clinic. [8] Dentist clinics do not prioritize the number of patients. New patients do not bring economic benefits to the dental clinic. Most of the new patients who come are patients who want to consult about the condition of their teeth and mouth, and in general, patients come with a toothache. Taqiyyah, La Ode, Paridah explained in their research that when a patient comes in with a toothache, there is not much a dentist can do. What can be done is to provide consultation and drug delivery services to patients.[9] If possible, simple curative measures can be taken to reduce the pain that the patient complains of, then at the next visit, curative measures can be taken to treat the main complaint felt by the patient. Economically, it is not profitable for the dental clinic.[7]

In contrast to patients who make repeat visits, after making the first visit, the next step is to evaluate the first visit results and carry out medical treatment for the patient's chief complaint. Dental clinics can provide their primary service or product at this stage, whether it be fillings, installation of braces, surgical treatment, or other medical treatment.[10] Dental clinics can attract dentist services, and the materials and lab services used are higher than the prices for consulting services and purchasing drugs so that the economic benefits obtained are much more significant. 


\section{RESEARCH METHOD}

This research was conducted from 26 December 2019 to 08 January 2020 for patients seeking treatment at an exclusive dental clinic in South Jakarta. The scope of this research is quality, service price, customer satisfaction, and customer loyalty.

The subjects of this study were patients who had visited/treated to an exclusive dental clinic in the South Jakarta area and had repeated visits at least twice to the same exclusive dental clinic.

\subsection{Population and sample}

The population is a general area consisting of objects/subjects with specific qualities and characteristics determined by the researchers studied and conclusions drawn. At the same time, the sample is part of the population to be studied. The population inthis study are patients who have visited/treated to an exclusive dental clinic in South Jakarta and made at least two visits to the same exclusive dental clinic. [11] While the sample in this study was at the time of the study, these patients were patients who had made repeated visits at least two times to the same exclusive dental clinic in South Jakarta and had previously visited other dental clinics. The sampling technique used in this study was purposive sampling using a sample size based on the minimum number of samples to be studied which was submitted by Barbara Linda, with the formula " $50+8(\mathrm{~m})$ " by focusing on the characteristics of the sample above. "m" referred to in the above formula is the number of independent variables used as research material. In this study, four factors were examined, namely quality, price, satisfaction, and loyalty. Then the number of sample sizes to be studied is $50+8(4)=82$ samples.

\subsection{Data analysis techniques}

Based on the hypothesis in this study, the data analysis method used is SEM (Structural Equation Modeling) analysis using smartPLS ver.3.0 software. Analyzing the research model with SEM can identify the dimensions of a construct and, at the same time, can measure the influence of the degree of relationship between the factors that have been identified.

\section{RESULT AND DISCUSSION}

\subsection{Research variables and indicators}

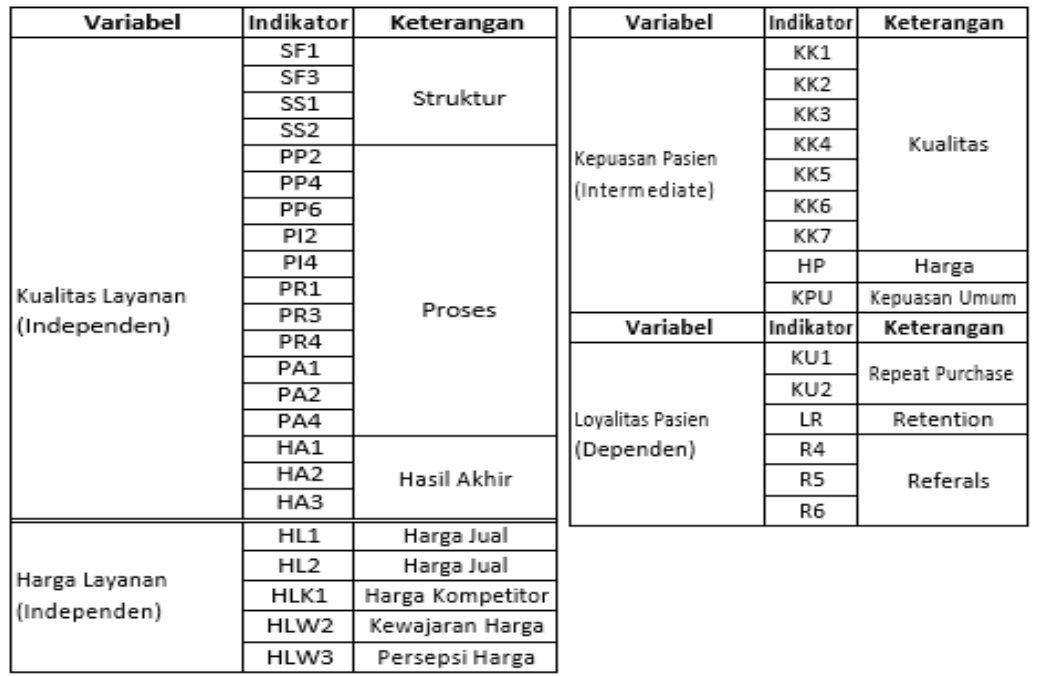

Figure 1. Researchvariables and indicators

In the table above, it can be seen that the service quality variable consists of 18 question indicators, five service price indicators, patient satisfaction nine questions indicators, and patient loyalty with 6 question indicators so that the total questions contained in the research instrument are 38 questions. 


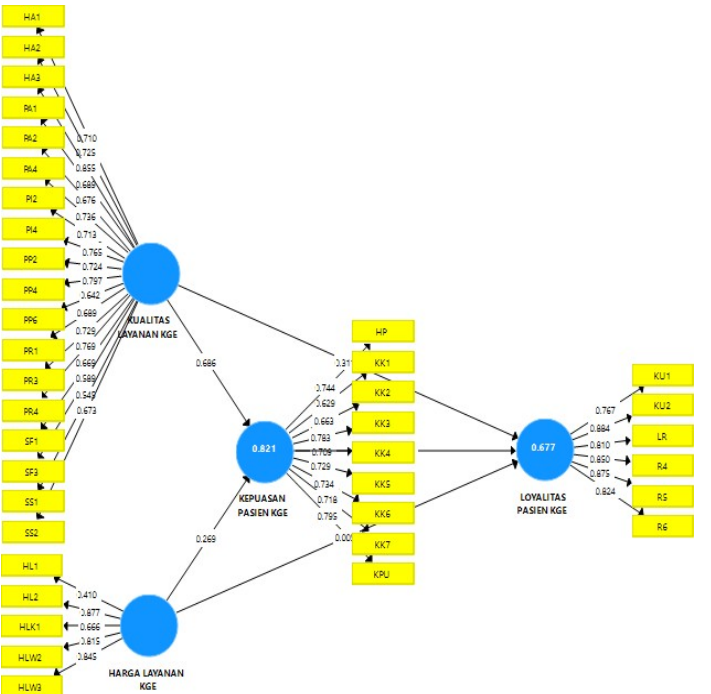

Figure 2. Relationship Model Framework for Quality, Price,Satisfaction with PatientLoyalty of Exclusive Dental Clinic
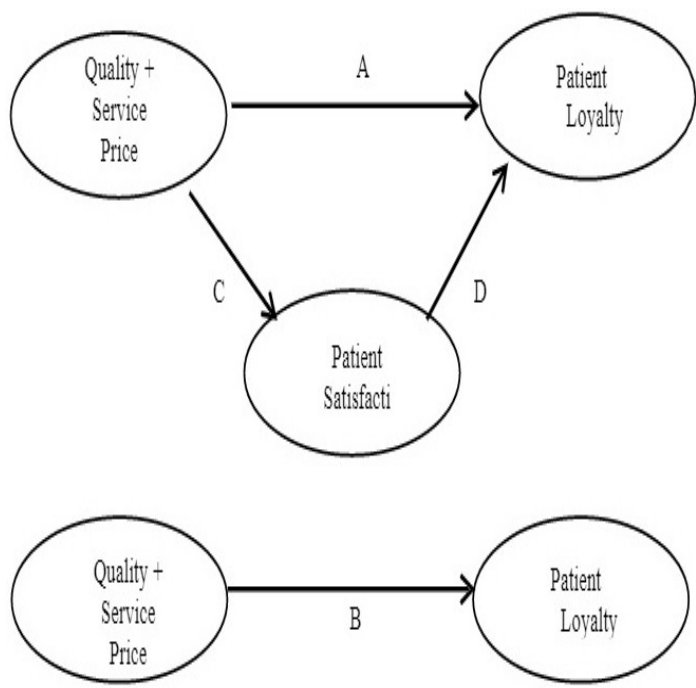

Figure 3. Analysis of mediating variables 


\subsection{Research variables and indicators}

If (C) and (D) are significant and (A) are not significant, then patient satisfaction is said to be a complete mediation variable. If (C) and (D) are significant, and (A) is also significant, where the coefficient (A) is smaller than (B), then customer satisfaction is said to be a partial mediation variable. If (C) and (D) are significant, and (A) is also significant, where the coefficient of (A) is almost the same as (B), then patient satisfaction is said to be not a mediating variable. If one (C) or (D) or both are not significant, it means that patient satisfaction is not a mediating variable.

The mediating variable was analyzed in this study, namely patient satisfaction, as a perfect mediating variable. This is because, in the framework of the research model, the values of $\mathrm{C}$ and $\mathrm{D}$ are significant, and $\mathrm{A}$ is not significant.[12]

\subsection{Research}

This research was conducted from 26 December 2019 to 08 January 2020 at several exclusive dental clinics in South Jakarta. [13] The scope of this research is quality, service price, customer satisfaction, and customer loyalty. Before the respondent fills out the questionnaire, the researcher first asks filtering questions to determine whether the respondent meets the desired requirements as a research sample.[14]

The research found that the highest number of treatments was dental fillings, as many as 33 respondents followed by scaling and bracket treatments, while the lowest was implants as many as one respondent.[15] It is interesting to discuss the type of treatment with the highest number of fillings. Riskesdas data, the highest prevalence of dental and oral disease is cavities, followed by the high prevalence of tartar and plaque. While bracket treatment occupies the third-highest position, aesthetic dental care has been increasing lately, especially for the middle-upper economic group in South Jakarta.[16]

The average cost for dental fillings is Rp. 1,374,242, with the lowest cost of Rp.600,000 and the highest cost of Rp. 4,000,000. This is above the standard cost of dental services for DKI Jakarta Province of Rp. 80,000 -Rp. 150,000 for dental fillings. [17] The high number of filling treatments at exclusive dental clinics in South Jakarta with costs above the standard tariff for dentistry services in the DKI Jakarta province illustrates the need for quality dental and oral care even though patients pay higher fees for their fillings. [18]This is by the research conducted by Gauthier that the middle-upper economic class society is more concerned with the quality of good dental care than the low price. [19] For tooth extraction treatment, as many as nine respondents, with an average treatment cost of Rp. 2,933,333, the cost of this treatment is far above the standard cost of dentistry services for theDKI Jakarta Province of Rp. 200,000 -Rp. 800,000. [20]For scaling treatment with 17 respondents, the average cost of treatment is $\mathrm{Rp}$. 538,235, which is above the standard cost of dental services for DKI Jakarta province, which is Rp. 180,000. [21]For bleaching treatments, brackets and implants are not often found in general dental clinics; this service is only available at dental clinics where there are specialist dentists at the dental clinic.[22]

\section{CONCLUSION}

Based on the research that has been done, the following conclusions are obtained. First, there is a significant effect between service quality and patient satisfaction at an exclusive dentist clinic in South Jakarta. Second, there is no significant effect between service quality and patient loyalty at an exclusive dentist clinic in South Jakarta. Third, service prices significantly affect patient satisfaction at an exclusive dentist clinic in South Jakarta. Fourth, there is no significant effect between service prices and patient satisfaction at an exclusive dental clinic in South Jakarta. Fifth, there is a significant effect between patient satisfaction and patient loyalty at an exclusive dental clinic in South Jakarta. Seventh, all of these factors have a significant effect on patient loyalty at an exclusive dental clinic in South Jakarta

\section{SUGGESTION}

Some suggestions that are recommended based on the results of this study to increase patient repeat visits at exclusive dental clinics in South Jakarta, among others, are as follows. First, service quality improvement should be paid more attention to. To increase patient satisfaction, which impacts the interest of repeat patient visits. Second, the price factor does not significantly affect patient satisfaction and loyalty. Instead of lowering prices, it would be better to install existing service rates but emphasize improving service quality. Third, increasing patient satisfaction can be done by emphasizing service quality in interactions between den- 
tists, clinic staff, and patients. Fourth, patient loyalty can still be improved by increasing service quality and dental clinic patient satisfaction.[23]

\section{REFERENCES}

[1] B. P. Statistik, "Badan pusat statistik,” Retrieved May, vol. 11, 2018.

[2] K. T. Moffa, Exploration of Two Alternative Approaches to Dual-Continua Mental Health Classification among High School Students. University of California, Santa Barbara, 2019.

[3] S. K. R. Indonesia, “APBN 2019: Pemerintah Alokasikan Rp20, 979 Triliun untuk Otonomi Khusus Aceh, Papua, dan Papua Barat,” Retrieved, vol. 5, no. 11, p. 2019, 2018.

[4] K. K. R. Indonesia, "Kelas Menengah Penggerak Ekonomi Indonesia,” Retrieved on January, vol. 22, 2019.

[5] S. Erawati, "Tingkat Pengetahuan Masyarakat Tentang Bantuan Hidup Dasar (BHD) Di Kota Administrasi Jakarta Selatan,” Skripsi, Univ. Islam Negeri Sarif Hidayatullah, Progr. Stud. Ilmu Keperawatan Fak. Kedokt. Dan Ilmu Kesehatan, Jakarta, 2015.

[6] P. Prawiroharjo and P. D. I. Meilia, "Dokter beriklan: sebuah tinjauan menurut Kode Etik Kedokteran Indonesia (KODEKI) tahun 2012,” J. Etika Kedokt. Indones., vol. 1, no. 1, p. 13, 2017.

[7] H. Wiworo and P. Eni, "Pendidikan dan Status Ekonomi dengan Kepatuhan Perawatan Gigi Tiruan Lepasan," 2017.

[8] M. S. Mahrous and T. Hifnawy, "Patient satisfaction from dental services provided by the College of Dentistry, Taibah University, Saudi Arabia,” J. Taibah Univ. Med. Sci., vol. 7, no. 2, pp. 104-109, 2012.

[9] B. E. Pjetursson and K. Heimisdottir, "Dental implants-are they better than natural teeth?," Eur. J. Oral Sci., vol. 126, pp. 81-87, 2018.

[10] A. Dawood and S. Patel, “The Dental Practicality Index-assessing the restorability of teeth,” Br. Dent. J., vol. 222, no. 10, pp. 755-758, 2017.

[11] B. D. Zeitlin, "Banking on teeth-Stem cells and the dental office,” Biomed. J., vol. 43, no. 2, pp. 124-133, 2020.

[12] Q. Aini, E. P. Harahap, and F. Faradilla, “The Effects of Sales Reports Business Intelligence on Employee Performance,” Aptisi Trans. Manag., vol. 4, no. 1, pp. 83-91, 2020.

[13] W. Setyowati, P. C. Kurniawan, A. Mardiansyah, E. P. Harahap, and N. Lutfiani, "The Role Of Duty Complexity As A Moderation Of The Influence Auditor's Professional Knowledge And Ethics On Audit Quality," Aptisi Trans. Manag., vol. 5, no. 1, pp. 20-29, 2021.

[14] K. Arora and A. S. Bist, "Artificial intelligence based drug discovery techniques for covid-19 detection," Aptisi Trans. Technopreneursh., vol. 2, no. 2, pp. 120-126, 2020.

[15] A. K. Badri, J. Heikal, Y. A. Terah, and D. R. Nurjaman, "Decision-Making Techniques using LSTM on Antam Mining Shares before and during the COVID-19 Pandemic in Indonesia," APTISI Trans. Manag., vol. 6, no. 2, pp. 167-180, 2022.

[16] A. S. Bein, Y. I. Graha, and A. P. Pangestu, "Pandawan Website Design Based Content Management System As Media E-commerce Transaction," Aptisi Trans. Technopreneursh., vol. 2, no. 1, pp. 87-97, 2020.

[17] P. Hendriyati, F. Agustin, U. Rahardja, and T. Ramadhan, "Management Information Systems on Integrated Student and Lecturer Data,” APTISI Trans. Manag, vol. 6, no. 1, pp. 1-9, 2022. 
[18] N. P. Lestari, Y. Durachman, S. Watini, and S. Millah, "Manajemen Kontrol Akses Berbasis Blockchain untuk Pendidikan Online Terdesentralisasi,” Technomedia J., vol. 6, no. 1, pp. 111-123, 2021.

[19] A. Asman, "Manajemen Operasional Digital terhadap faktor-faktor yang berhubungan dengan kejadian Pneumonia di Poliklinik Paru di RSUD Pariaman," ADI Bisnis Digit. Interdisiplin J., vol. 2, no. 2, pp. 13-19, 2021.

[20] A. S. Anwar, U. Rahardja, A. G. Prawiyogi, and N. P. L. Santoso, "iLearning Model Approach in Creating Blockchain Based Higher Education Trust,” Int. J. Artif. Intell. Res., vol. 6, no. 1, 2022.

[21] U. Rahardja, A. N. Hidayanto, N. Lutfiani, D. A. Febiani, and Q. Aini, "Immutability of Distributed Hash Model on Blockchain Node Storage," Sci. J. Informatics, vol. 8, no. 1, pp. 137-143, 2021.

[22] U. Rahardja, E. P. Harahap, and D. D. Christianto, "Pengaruh Teknologi Blockchain Terhadap Tingkat Keaslian Ijazah,” Technomedia J, vol. 4, no. 2, pp. 211-222, 2021.

[23] D. Apriani, A. Williams, U. Rahardja, A. Khoirunisa, and S. Avionita, "The Use of Science Technology In Islamic Practices and Rules In The Past Now and The Future,” Int. J. Cyber IT Serv. Manag., vol. 1, no. 1, pp. 48-64, 2021. 